\title{
ANALYSIS OF METHODICAL APPROACHES TO MEASURE ENTERPRISE'S ECONOMIC SECURITY
}

\author{
Bugay V. Z., Gorbunova A. V., Dibrova V. O. \\ Zaporizhzhia National University \\ Ukraine, 69600, Zaporizhzhia, 66 Zhukovsky str \\ bugai_v_z@ukr.net \\ ORCID 0000-0002-3568-1577
}

Key words:

development, business security, financial indicators, resources, reserves.
Business security means its continuous, balanced and sustainable development ensured by the effective application of all types of available resources, and reflected in the upward trends of economic and financial indicators. It has been proved that the system of indicators which determines enterprise's economic security is diversified, complicatedly organized, though the variety of indicators is not always informative. Economic indicators are closely interrelated. Therefore, only their systematic definition can provide a true picture of business` economic threats. It has been identified that there are different approaches to assess threats to enterprise`s economic security in scientific literature. The main are the indicator and resource-functional approaches. It has been determined that the main disadvantages of the first approach are a substantial number of indicators, difficulties to measure their marginal values, not taking into account changes of external and internal environment. It has been specified that nowadays application only of the resource-functional approach to assess business economic security is irrational, since the security itself is defined as the ability of an enterprise to face threats and ensure its development in the future. It has been stated that it is necessary to assess threats to enterprise`s economic security not only in cases of economic hardship, but also in order to forecast, avoid, effectively and rationally use its economic capacity.

The main challenges of enterprise`s economic threats assessment are to reveal trends and patterns in business development in the period under study, identify unfavorable fields of financial and economic activities and their impact on enterprise`s economic security, find out the reserves that could be used to strengthen it.

\section{АНАЛІЗ МЕТОДИЧНИХ ПІДХОДІВ ІДЕНТИФІКАЦІЇ ЕКОНОМІЧНОЇ БЕЗПЕКИ ПІДПРИСМСТВА}

\author{
Бугай В. 3., Горбунова А. В., Діброва В. О.
}

Запорізький національний університет

\author{
Україна, 69000, м. Запоріжжя, вул. Жуковського, 66
}

\section{Ключові слова:}

розвиток, безпека підприємства, фінансові індикатори, ресурси, резерви.
Безпека підприємства передбачає безперервний, збалансований його стійкий розвиток, що забезпечується за допомогою ефективного використання усіх видів наявних ресурсів, яке відображається в позитивній динаміці економічних і фінансових показників. Визначено, що система показників, що визначає економічну безпеку підприємства характеризується різноманіттям, важко підлягає структуризації, їх значна кількість не завжди несе необхідне інформаційне навантаження. Економічні показники тісно пов'язані між собою. Тому тільки їх системне визначення може дати об'єктивну картину економічних загроз підприємства. Встановлено, що у наукових джерелах існують різні підходи до оцінки загроз економічної безпеки підприємств. Основними 3 таких підходів $є$ індикаторний і ресурсно-функціональний. Визначено, що основними недоліками першого підходу $€$ значна кількість індикаторів та складність визначення граничних їх значень, а також не врахування змін зовнішнього та внутрішнього середовища. Узагальнено, що застосування лише ресурсно-функціонального підходу до оцінювання економічної безпеки підприємства в сучасних умовах $є$ необгрунтованим, оскільки власне безпека трактується як спроможність підприємства протистояти загрозам та забезпечувати його розвиток у майбутніх періодах. Недоліком даного підходу також є складність визначення індикаторів та їх граничних значень за усіма функціональними складовими. Обгрунтовано, що оцінку загроз економічної безпеки підприємства необхідно проводити не тільки у випадках економічних труднощів, але й для того, щоб їх передбачати, уникати, ефективно та раціонально використовувати економічний потенціал. Основні проблемні питання, що виникають та враховуються під час проведення оцінки економічних загроз підприємства, полягають у виявленні тенденцій та закономірностей розвитку підприємства в досліджуваному періоді, визначення проблемних місць фінансово-економічної діяльності та ступеня їх впливу на економічну безпеку підприємства, виявленні резервів, які можна використати для зміцнення економічної безпеки. 


\section{Statement of the problem}

The formation of market relations in Ukraine and increased competition in all spheres of economic activity of national and world markets have significantly exacerbated the problem of survival and ensuring the necessary level of economic security for domestic businesses, which requires appropriate methods of assessment. Analysis of different approaches to assessing economic security enterprises indicates that this problem is not yet sufficiently studied. In the complex modern economic conditions, the development of methods for assessing the economic security of the enterprise is of great methodological importance, which is associated with the need for constant protection from adverse conditions of external and internal environments.

\section{Analysis of recent research and publications}

Such domestic scientists as Y. Gorbachuk, N. Kushnir [1], O. Zhovna, O. Molodetska [2], N. Gritsyuk [3], O. Sudakova [4], V. Danilenko [5], A. Matviychuk [6], M. Reta, A. Ivanova [7] and others.

Scientists note that an objective assessment of the economic security of the enterprise is the basis of its operation and development. In their research, they argue that each method has its own conditions and limits of application. Most scientists believe that determining the state and threats to economic security of the enterprise requires the use of indicator method, which involves determining the level of economic security by comparing the actual performance of the enterprise with the limit values of indicators of its level. All researchers point out that there is a connection between the economic security of the enterprise and the provision of financial resources.

\section{Forming the goals of the article}

The objective of the article is to study the methodological approaches to assessing the economic security of the enterprise, identifying their shortcomings and forming conclusions about the feasibility of their use in the practice of assessing the economic security of corporate structures.

\section{The main material of the research}

The assessment of the economic security of the business entity in order to determine the main directions of its further development is currently relevant for industrial enterprises. After all, the presence of profit and even a high level of profitability is often accompanied by a fairly low level of strategic security of economic entities, due primarily to low levels of competitiveness and technical and technological potential, a high level of dependence on environmental factors.

Note that by economic security we mean the ability of the enterprise to adequately respond to the threat of destabilizing factors of the internal and external environment on economic activity.

In order to ensure the self-preservation of the enterprise and its sustainable development, it is necessary to determine the level of economic security, and on its basis to select tools to effectively use existing potential, improve management, constantly update technology and improve the information base.
The economic literature identifies a number of methods for assessing the level of economic security of the enterprise (Fig. 1).

Analysis of the literature shows that the most common method of assessing the level of economic security of the enterprise is an indicator approach, which involves comparing the actual values of safety indicators with the limit values of indicators, i.e. those whose failure leads to threats to economic security [1].

In relation to this approach, scientists O. Zhovna and O. Molodetskaya claims that the assessment of the real state of economic security at the enterprise is established by comparing the actually achieved performance indicators with their regulatory level. Reliability - a state when the company sells competitive products for a long time, receives a profit sufficient for industrial and social development, is liquid and creditworthy. If the share of actually achieved coefficients that do not correspond to the optimal values ranges from 10 to $50 \%$, the activity of the enterprise is considered relatively reliable. If negative deviations of more than $50 \%$ of the calculated coefficients are detected, it can be argued about the financial unreliability of the enterprise [2].

We believe that the main disadvantages of this approach are the large number of indicators and the difficulty of determining their limit values, as well as not taking into account some changes in the external and internal environment. It is also problematic for enterprises to determine the threshold levels of indicators, and in addition, they will be different for each individual enterprise. It should be noted that the simple calculation and control of these indicators is clearly not enough to ensure the economic security of the enterprise.

Representatives of the resource-functional approach [3; 4] propose to determine the level of economic security based on an assessment of the degree of use of resources of economic entities for each functional component, and then determine the integrated indicator by experts. In this case, the functional structure of financial activities and, accordingly, the economic security of the enterprise is determined by the following components: budget; monetary; currency; banking; investment; stock; insurance. The authors propose to take into account the importance of components of economic security.

We consider it necessary to note that the application of only a resource-functional approach to assessing the economic security of the enterprise in modern conditions is unfounded, because security is interpreted as the ability of the enterprise to withstand threats and ensure its development in future periods. The disadvantage of this approach is also the difficulty of determining the indicators and their limit values for all functional components.

Scientists also offer for practical use an approach to assessing the economic security of the enterprise based on assessing the probability of its bankruptcy. Many models for predicting the bankruptcy of the enterprise have been developed, which can be divided into two groups: quantitative (Beaver, Taffler and Forest model, Altman model, universal discriminatory model, R model) and qualitative (Argenti model). 


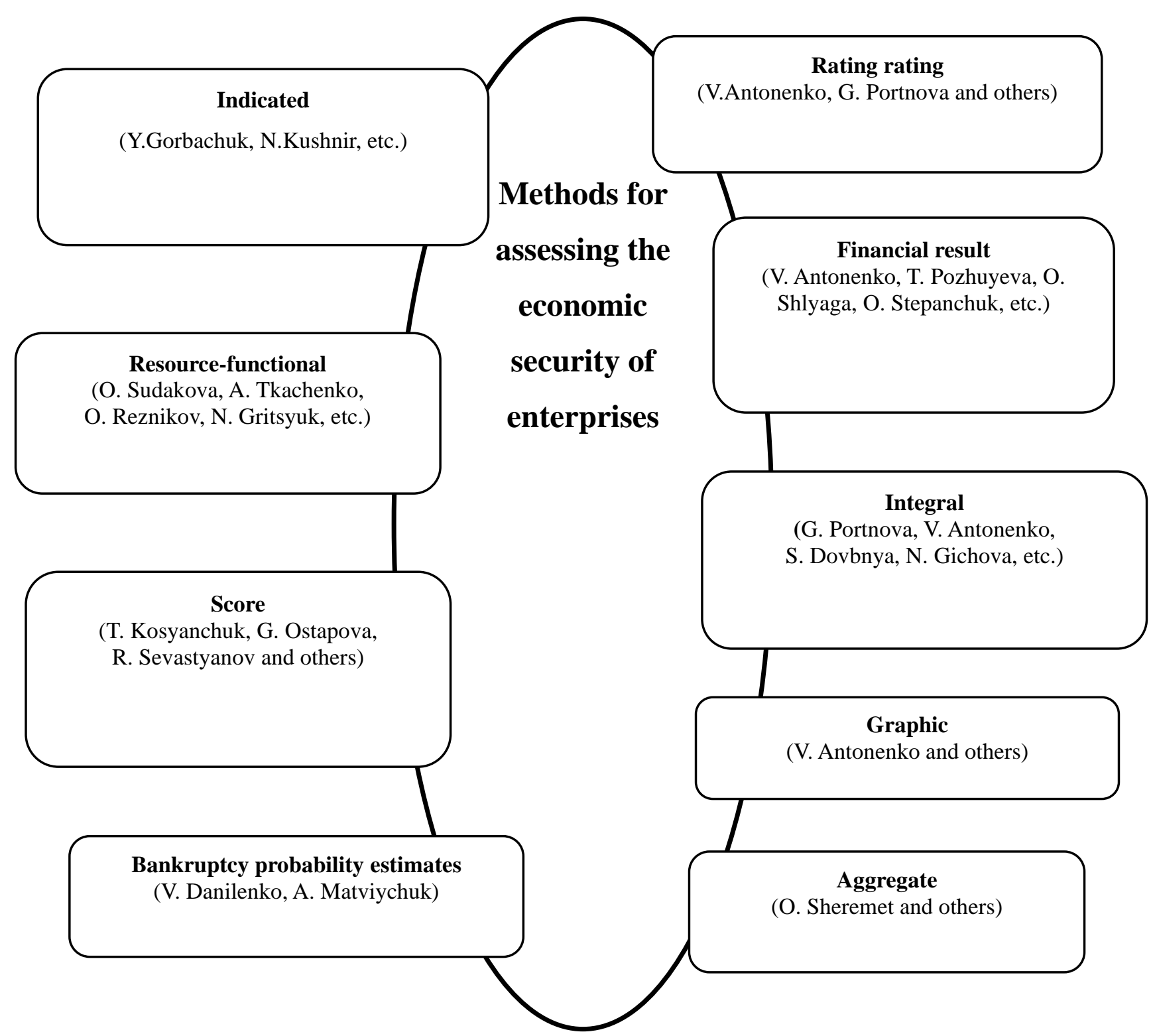

Fig. 1. Methods for assessing the level of economic security of the enterprise

Source: Compiled for [1-13]

Most of these models are the result of the development of scientists in a stable market economy and in the presence of long-term mass statistics (England, Germany, USA, etc.), where the concept of bankruptcy is historically formed. These models may not be acceptable to domestic enterprises due to different inflation rates, phases of the production cycle, differences in capital, energy and labor intensity of production, labor productivity, underdevelopment of the Ukrainian stock market, different "tax climate", which requires clarification set and criteria values of indicators, their adaptation to modern conditions of development of the Ukrainian economy as their size essentially influences results of calculations and correctness of conclusions.

It should be noted that domestic scientists such as V. Danylenko, A. Matviychuk and others. Also, developed proposals for forecasting the bankruptcy of insolvent enterprises $[5 ; 6]$. However, the developed models for predicting the probability of bankruptcy have not received general recognition, and therefore it is problematic to use them to assess the level of economic security of enterprises.

In the source [7] the calculation of integrated indicators of the level of financial security of the enterprise is proposed to be carried out by reducing the indicators of financial stability, liquidity and solvency into a single indicator based on their normal value. Thus, for an estimation of a level of financial safety of the enterprise three levels are offered: stable, satisfactory, critical.

The disadvantages of the proposed methodological approach to assessing the financial security of the enterprise, we believe, include the following:

- the authors do not substantiate why they took to calculate and assess the level of financial security of the enterprise is the indicators of financial stability, liquidity and solvency. It should be noted that liquidity and 
solvency ratios are closely interrelated, and therefore their joint use, we believe, may lead to unsubstantiated conclusions;

- it is not specified what is the normal value of the indicators used to calculate their normative value.

Researchers S. Dovbnya, N. Gichova [8] offer a methodological approach "Three-dimensional diagnosis of the level of economic security of the enterprise", which involves assessing the level of economic security of the enterprise depending on the time parameter according to which it is determined.

According to this methodological approach, the overall level of economic security of the enterprise is determined based on the level of its current, tactical and strategic security.

The economic security of the enterprise, according to the authors, is determined primarily by the level of its current security, as solvency is an essential condition for the life of the business entity. The importance of tactical security increases as the financial and economic stability of the enterprise.

We believe that the disadvantages of the analyzed approach include the difficulty of collecting information to calculate the indicators proposed by the authors, as well as the subjective assessment of the coefficients of significance of selected indicators used to assess current, tactical, strategic and therefore overall economic security.

Studies show that the assessment of the level of economic security can be carried out quite effectively using a graphical approach, which, according to its authors, helps to better perceive and not only characterize the current state of the enterprise, but also the state of security to strive for [9].

One of the methods of assessing the state of economic security can be a score. According to the authors, it simplifies the conduct of economic diagnostics, allows for constant monitoring of those indicators that determine the state of economic security. Carrying out a point assessment involves the development of a scale for each component with the definition of possible discounts on certain circumstances. Analysis of these deviations, identifying their causes can be the basis for the formation of appropriate strategies and programs to ensure the stability of the enterprise [9].

The definition of the class (level) of safety is based on the limit values of indicators and their rating. For analysis, scientists propose to use the following indicators: the coefficient of autonomy; inventory turnover ratio; return on assets for net income; financial risk ratio; absolute liquidity ratio.

Before approaching the definition and assessment of the level of financial security, it is necessary to make the following remarks:

- the authors do not substantiate why it is advisable to use such a set of indicators, their importance in shaping the security of the enterprise;

- normative values of the specified indicators are not substantiated;
- the branch features of formation of the offered indicators are not considered.

From a strategic point of view to assess the level of security of enterprises

V. Antonenko [10] and T. Pozhuyeva [11] propose to use the indicator of financial result achieved by the enterprise. In their opinion, the use of profit as a criterion of financial security of the enterprise has the following advantages: first, profit is an integrated criterion of efficiency of its activities; secondly, it is a subject of financial interests; third, it is the main source for its strategic development.

Our research shows that the net profit indicator has a number of disadvantages, namely:

- profit is recognized after the sale, not after the receipt of funds for shipped products;

- such expenses as capital investments, taxes paid at the expense of profit, debt payments, etc.; do not take part in the calculation of profit;

- financial transactions (for example, obtaining and repaying loans, targeted financing) are also not reflected in profits, but cause cash inflows or outflows.

In connection with the above, we believe that the cash flow rate more realistically characterizes the level of economic security of the enterprise than profit.

The level of economic security O. Shlyaga, O. Stepanchuk [12] propose to determine by comparing the economic results of the enterprise with their reference level, which can be achieved in the absence of all threats. However, the authors do not specify how to calculate this figure.

Scientists V. Antonenko and G. Portnova [9] in order to quickly determine the level of financial security of the enterprise propose to use an approach based on rapid rating assessment.

The final rating, according to the authors, takes into account all the most important indicators of financial and economic activities that best characterize the financial security of the enterprise: the ratio of own funds; coverage ratio; intensity of turnover of advanced capital; efficiency of enterprise management; return on equity.

The disadvantages of this approach, in our opinion, include an unreasonable set of indicators.

The essence of the aggregate approach is to calculate the estimated aggregates calculated on the basis of financial statements. The most common example of the use of an aggregate approach in the assessment of economic security is the construction of balance models of compliance of the value of stocks with the sources of their formation. The assessment is based on the analysis of the financial stability of the enterprise, the degree of which is determined based on the adequacy of working capital (own or borrowed) for the implementation of production and marketing activities [13].

Note that this is a very narrow approach to assessing the level of financial security of the enterprise, because in addition to working capital in the financial activities of the enterprise involved its own fixed capital, profits, investments, securities and others. 


\section{Conclusions}

The analysis of methodological approaches to assessing the level of economic security of the enterprise shows that:

- assessment of the level of economic security of the enterprise based on the analysis of the dynamics of one or more indicators does not take into account its systemic nature, and therefore is ineffective;

- in a significant part of the methods the impact of threats on the level of financial security is not distinguished and quantified. Therefore, it is advisable to take into account the degree of risk of transition from a state of financial security to a state of financial crisis in terms of relevant factors:

- in the considered approaches to the assessment of the level of economic security of the enterprise the main attention is paid to the assessment of the level of security in retrospective and current dimension, while the most valuable are forecast estimates for the future.

Thus, determining the level of economic security of the enterprise should be based on the formation of a system of criteria for prospective assessment for each individual enterprise, based on the specifics of its financial and economic activities.

\section{References}

1. Gorbachuk Y.A. and Kushnir N.B. (2007),Economichna diagnostika: Interactuvnui complex navchalnometoduchnogo zabespechenya [Economic diagnostics: Interactive complex of educational and methodical providing],NUVGP, Rivne, Ukraine.

2. Zhovna O.M. , Molodetska O.M. (2011) "Assessment of financial security of enterprises on the basis of separate diagnostics of the crisis situation for the current and past periods", Electronic scientific professional publication "Effective Economy" Dnipro, available at: http://www.economy.nayka.com.ua/?op=8\&w.

3. Gritsyuk N.A. (2008) Metodychni pidkhody do obgruntuvannya indykatoriv otsinky rivnya finansovoyi bezpeky pidpryyemstva. [Methodical approaches to substantiation of indicators of an estimation of a level of financial safety of the enterprise], Problems of science, Ukraine, Kyiv № 6

4. Sudakova O.I. (2008) Ekonomichna diahnostyka bankrut·stva pidpryyemstva [Economic diagnosis of enterprise bankruptcy], Ekonomichnyy prostir, Ukraine, Dnipro №14[in Ukrainian].

5. Danylenko VA (2009) "Application of bankruptcy diagnosis models for assessing the financial stability of industrial enterprises of Ukraine”, Naukovyy visnyk Akademiyi munitsypal'noho upravlinnya, Ukraine, Kyiv, available at: http://www.nbuv.gov.ua/portal/Soc_Gum/Nvamu/ ekon/2009_7/09 dvaeou.pdf.

6. Matviychuk A.V. (2010) Diahnostyka bankrut·stva pidpryyemstv [Bankruptcy diagnosis of enterprises], Kyiv № 4[in Ukrainian]. .

7. Reta M.V., Ivanova A.O. (2013) Methodical approaches to assessing the level of financial security of the enterprise [Metodychni pidkhody do otsinky rivnya finansovoyi bezpeky pidpryyemstva], Visnyk NTU «KHPI», Ukraine Kharkiv ,№ 21 (994).

8. Dovbnya S.B., Gichova N.Yu.(2008) "Diagnosis of economic security of the enterprise as a tool for determining the directions of its innovative development”, Ekonomichnyy visnyk NHU, Ukraine, Dnipro, №3 available at: http://ir.nmu.org.ua/bitstream/handle/123456789/406/2008_3_p036-042.pdf?

9. Antonenko V.M. , Portnova G.O. (2012) "Research, testing and development", Zbirnyk naukovykh prats' Natsional'noho universytetu derzhavnoyi podatkovoyi sluzhby Ukrayiny, Ukraine, Kyiv, [in Ukrainian].

10. Antonenko V.M. (2012) Finansovyy rezul'tat yak chynnyk vplyvu na finansovu bezpeku pidpryyemstva [Financial result as a factor influencing the financial security of the enterprise], Scientific and technical collection,Ukraine,Kharkiv, №108. [in Ukrainian].

11. Pozhuyeva T.O. (2011) "Ensuring economic security is a guarantee of stable functioning of an economic entity", Teoretychni i praktychni aspekty ekonomiky ta intelektual'noyi vlasnosti: zb. nauk. prats': [in Ukrainian].

12. Shlyaga O.V. , Stepanchuk O.I. "Analysis of approaches to assessing the level of economic security of an industrial enterprise" available at: http://www.zgia.zp.ua/gazeta/evzdia_8_037

13. Sheremet O. O. (2005) Finansovyy analiz [Financial analysis], Kondor, Ukraine, Kyiv[in Ukrainian]. 